\title{
The Sydney History Group: From the Beginning
}

JILL ROE

$\mathrm{F}$

ormally speaking, the Sydney History Group (SHG) began in 1977, and ran for almost 20 years to 1995, when the last of its seven books appeared. ${ }^{1}$ The books all presented original research on aspects of Sydney history and were edited by members of the Group, all whom are here today except for first president, the Warrnambool-born economic historian and urbanist Max Kelly. ${ }^{2}$ His MA on the history of Paddington, later published as A Paddock Full of Houses in 1978, set a new standard in suburban history and whose outline for a history of Sydney delivered to an informal interdisciplinary gathering of economic historians in the early seventies was ahead of its time. Max died too soon in 1996.

Mostly the chapters we published had been delivered as part of a regular program of meetings each year, these being held at members' houses or interesting historic sites such as Randwick Hospital - the old 
Children's Asylum building - on a Saturday afternoon or evening. The Group also published a newsletter, naughtily entitled The Sydney Gazette, which contained news and reviews, even from time to time items of research, and ran the occasional conference, the first at the National Trust centre on Observatory Hill, another at Sabine Erika's weekender in the Blue Mountains. These days all this activity would be called a project and cost a mint. Actually it was more often than not fun especially the meetings.

Here I am primarily concerned with the pre-history of the Group. And I am putting myself in. I was right into urban history in those days, as were many of us. The dynamic was partly personal, partly historiographical; and of course the balance varied from person to person. Some participants were city-born and bred, such as the young Peter Spearritt, though even his background was just a much Brisbane as Sydney. Others, like Max Kelly and me, were from rural and regional Australia. As Graeme Davison once pointed out with respect to my good self, but more widely applicable, the 1950s saw the last big wave of ruralurban migration in this country. ${ }^{3}$

Timing is important in understanding the rising interest in urban history in the mid twentieth century. In Britain, this is associated especially with the name of Asa Briggs, author of Victorian Cities (1963), which contained a crucial chapter on 'Marvellous Melbourne'. In America, the urban sociology that began in Chicago in the early decades of the twentieth century was well-established, and as early as 1940 the distinguished American historian Arthur Schlesinger Snr was urging his colleagues to focus their energies on the cities. Thus by the 1960s the Atlantic seaports were being studied afresh, as well as the booming midwestern cities. Here in Australia the call came later, in 1960, when Asa Briggs was a Visiting Scholar at the University of Sydney. Delivering the George Judah Cohen Memorial Lecture there that year on 'Historians and the Study of Cities', Briggs highlighted the high proportion of urban dwellers in Australia apparent from the late nineteenth century, the differences between Sydney and Melbourne at that time, and the lack of research into urban growth subsequently. The time had come he urged to recognise that: 'A city is a society in depth as well as society in space'. ${ }^{4}$

I hope this pre-history doesn't sound too much like scholasticism. It was certainly challenging at the time. For there is another aspect to the matter of timing. The Briggs lecture was delivered in 1960, a mere two years after the publication of that key work in Australian history, Russel Ward's The Australian Legend, which was published in 1958. As it happens, I have been re-reading The Australian Legend and I'm more 
impressed by the way it was done than before. At the time though - I was a student at the University of Adelaide, our first planned city if you don't count Hoddle's Melbourne - it seemed to me like a backward step, of little real interest. For me, Briggs on nineteenth century Melbourne was where it was at, and that is where I first focussed my research as a postgraduate student at the Australian National University. From that research came quite a few articles on the cultural history of cities and later my first book, Marvellous Melbourne: The emergence of an Australian city, published in 1974 in a series intended primarily for final year school and first year university students. Until the Franklin biography it was my best selling title and has always earned most in public lending rights.

By then, however, I was well and truly settled in Sydney. Again, it was a matter of timing, with Macquarie University just beginning, and the city an obvious challenge to a stack of new people. For me the turning point probably came about then, with - at last - study leave in the UK. After seven years at the mast, we historians at Macquarie were actually allowed to take a year's study leave! What a great thing that turned out to be. With Beverley Kingston, I set off for London mid-1974. Bev was then in the pre-release stage of My Wife, My Daughter and Poor Mary Anne (1975) and I was contracted to produce a reader entitled Social Policy in Australia 1901-1975 (1976). In addition to working in the wonderful research libraries London affords, we also travelled to Leicester by train every Wednesday during the academic year 1974-5 to attend a seminar on the Victorian city run by H. J. Dyos, then best known for Victorian Suburb: a study in the growth of Camberwell (1961).

Dyos may have looked a bit like a well-fed British businessman, but he had with Michael Woolf recently published a lavishly produced twovolume collection entitled The Victorian City: Images and Realities that I knew about from teaching modern British history. At his seminar we sat quiet as mice, taking in the words of practically every up and coming urban historian in Britain. We heard, for example, studies of residential segregation in 1870s Cardiff, petty landlordism in the nineteenth-century city and penny readings as part of the middle-class mission to civilize the working class. On return, as required after leave in those days, I gave a staff seminar at Macquarie, which appeared in the Australian Historical Association [AHA] Bulletin in December 1975. It was entitled 'History Goes to Town' and offers a critical account of all that I'd seen and learned on that score. That report, lavishly buttressed with criticisms of the new urban history, especially from the radical Left, now seems scarcely to convey the intellectual dynamic inherent in that Dyos seminar. Nonetheless, as I put it in that AHA Bulletin report, 'Urban 
history as being practised today... is actually helping us to see the world in a new way'. ${ }^{5}$

I could say more about visiting British cities at that time, for example Manchester. But the time had come to try 'To see [our own] world in a new way'. Sydney was before us. And there was movement in that direction right across the disciplines. The new urban history had to be interdisciplinary. This much can be seen from the Group's first publication, Nineteenth Century Sydney: Essays in Urban History (1978) edited by Max Kelly. It contained eleven chapters, beginning with economic historian Barrie Dyster's wonderfully titled 'The Discrete Interest of the Bourgeoisie, before the Age of Gold' and concluding with chapters on researching the historical demography of inner Sydney by geographer Peter Curson, sources for Sydney history in the State Archives by archivist Baiba Berzins and 'Sydney 1800-1900: A select bibliography' by Peter Spearritt, a political scientist. In between, in addition to Max Kelly's own contribution, 'Picturesque and Pestilential: The Sydney Slum Observed', there were chapters on Sydney and the rail by Garry Wotherspoon and David Clark on the city's water supply, both like Max economic historians. Architect Norman Edwards wrote on the early CBD and social historians Alan Roberts on planning Sydney's transport, Lesley Lynch on Mort's Dock and Balmain labour and Shirley Fisher (now Fitzgerald) on Sydney women and the workforce.

One reviewer of Nineteenth Century Sydney memorably said: what's all this, this is not a group. But that was not the point. By the mid-1970s diverse intellectual currents were coming together. Others came in on slightly different waves from me, from geography and politics, from town planning and economics, literature even: the point was that there was enough going on to make the Sydney History Group a viable collective effort. The seminars actually began in late 1975 when a constitution was drawn up and an executive duly elected.

In 1982, the first conference to be independently mounted by the Australian Historical Association, itself a relatively new organization, was held at the University of NSW. And the Sydney History Group was there, offering a symposium on The State of Urban History. You'll notice that the speakers came from Sydney (me), Perth (the late Tom Stannage) and Melbourne (Graeme Davison). That's because by then there were urban history groups in most of the capitals. As in a century earlier, the 1980s were the heyday of the city. However, the Group and the approach it advocated were already being challenged by the rise of social history, and that unstoppable trio, class, gender and race. Not that these subjects were absent from urban-focused research, but there they were meant to 
be part of the larger story, dependent not independent variables as it were. Unfortunately, as the 1982 panellists reported, there were problems with the new genre: not only was it overly quantitative and terribly labour intensive, it lacked coherence. Dyos had said the new urban history would be 'a salient of social history'. But social history, no matter how popular, would soon have the same problems, on an even larger scale. Meanwhile, the sad decline of economic history robbed the approach of its most likely sustainer. Several early participants were originally economic historians. As for me, I had always been at an angle, contributing as editor of Twentieth-Century Sydney: Studies in urban and social history (1980) with chapters on odd bods at Balmoral and Castlecrag; and of late I've been following writer Miles Franklin through a number of urban contexts, from 1890s Goulburn to Chicago and London and back to suburban Sydney through the first half of the twentieth century.

That takes me far too far from the story of the Sydney History Group. I've emphasised that the Group emerged in the mid-1970s in the context of a more general rise in interest in urban history. At the time, too, there was also a build-up of pressures for urban reform, here as elsewhere. The Group's prehistory and beginnings did after all coincide with the rise and fall of the Whitlam Labor government.

Jill Roe AO is emeritus professor in modern history at Macquarie University

\section{IN MEMORIAM}

News of the sudden death of Tom Stannage in Perth on 4 October 2012 came through as I was revising this paper for publication. He was a good colleague and friend and it's a sad loss for history. I would like to dedicate this paper to his memory.

\section{ENDNOTES}

${ }^{1}$ Sydney History Group titles are Max Kelly (ed), Nineteenth-Century Sydney: Essays in Urban History, Sydney University Press in association with the SHG, Sydney, 1978; Twentieth-Century Sydney: Studies in urban and social history, Hale \& Iremonger in association with the SHG, Sydney, 1980; Garry Wotherspoon (ed), Sydney's Transport: Studies in Urban History, Hale \& Iremonger with the SHG, Sydney, 1983; Max Kelly (ed), Sydney: City of Suburbs, UNSW Press with the SHG, Sydney, 1987; Graeme Aplin (ed), A Difficult Infant: Sydney before Macquarie, UNSW Press with the SHG, Sydney, 1988; John Shields (ed), All Our Labours: Oral Histories of working Life in Twentieth Century Sydney, UNSW Press with the SHG, Sydney,1992; and Shirley Fitzgerald and Garry Wotherspoon (eds), Minorities: cultural diversity in Sydney, State Library of NSW Press with the SHG, Sydney, 1995.

${ }^{2}$ SHG Presidents were Max Kelly, Jill Roe, Sabine Erika, Carolyn Allport, Graeme Aplin and Paul Ashton.

${ }^{3}$ Graeme Davison, 'The Exodists', History Australia, vol 2, no 2, June 2005.

${ }^{4} \mathrm{p} 18$.

${ }^{5} \mathrm{p} 20$. 